\title{
Skrining Isolat Bakteri Actinomycetes dari Sumber Air Panas Ai' Sipant Lotup yang berpotensi sebagai Agen Antifungi terhadap Fungi Malassezia sp. (M1).
}

\author{
Nurjanah $^{1}$, Rahmawati ${ }^{1}$, Novik Nurhidayat ${ }^{2}$ \\ ${ }^{1}$ Program Studi Biologi, Fakultas MIPA, Universitas Tanjungpura, Jln. Prof. Dr. H. Hadari Nawawi,Pontianak \\ ${ }^{2}$ Bidang Mikrobiologi, Lembaga Ilmu Pengetahuan Indonesia (LIPI), Cibinong, Bogor \\ Email korespondensi : nurjanah@student.untan.ac.id
}

\begin{abstract}
Abstrak
Actinomycetes is a filametous gram-positive bacteria. This group of bacteria can produce bioactive compounds, one of which is antifungal compounds. This study aims to determine the antifungal activity of Actinomycetes isolates from hot springs Ai 'Sipant Lotup in Sanggau Regency, West Kalimantan, to against Malassezia sp. (M1) through antifungal activity test using paper disc diffusion method. Actinomycetes isolates which have antifungal activity against Malassezia sp. (M1) are Microbispora sp. (S311A) and Streptomyces sp. (H2232). Based on the classification of inhibitory zone activity, the isolates were classified as strong (S311A) and medium (H2232) to against Malassezia sp. (M1).
\end{abstract}

Keyword : Actinomycetes, antifungal, Microbispora sp. (S311A), Streptomyces sp. (H2232), Malassezia sp.(M1).

\section{PENDAHULUAN}

Actinomycetes merupakan bakteri gram positif berbentuk filamentus dan mampu membentuk spora. Bakteri kelompok ini mengalami pembelahan kompleks dan dapat menghasilkan beragam senyawa bioaktif dibandingkan dengan kelompok bakteri lain (Dewi, 2014). Menurut Berdy (2005) Actinomycetes ialah golongan mikroba terbesar yang mampu menghasilkan senyawa bioaktif, dari 22.500 senyawa bioaktif 45\% diproduksi oleh golongan Actinomycetes. Senyawa aktif yang dihasilkan Actinomycetes umumnya digunakan sebagai antimikroba, antikanker, maupun antitumor. Actinomycetes juga dikenal sebagai agen penghasil antibiotik. Sekitar $70 \%$ antibiotik yang telah ditemukan dihasilkan oleh Actinomycetes terutama dari angota genus Streptomyces.

Actinomycetes juga berpotensi sebagai agen antifungi. Senyawa yang dihasilkan antara lain Kasugamycin oleh anggota spesies Streptomyces kasugaensis, polyoxin B dan D oleh anggota spesies Streptomyces cacaoi var. asoensis. Metabolit yang dihasilkan tersebut dapat menghambat proses sintesis dinding sel jamur (Barka et al., 2016). Potensi Actinomycetes juga dijelaskan dalam penelitian yang telah di lakukan beberapa ilmuan. Salah satunya Deepa et al. (2013) melaporkan sebanyak 16 isolat yang diisolasi di wilayah India berpotensi sebagai agen antimikroba 4 di antaranya berpotensi sebagai agen antifungi yakni Streptomyces griseoflavus, Streptomyces cyaneus, Streptomyces exfoliatus dan Streptomyces albus.

Sumber air panas Ai' Sipatn Lotup memiliki arti nama, yaitu Ai' artinya air, Sipatn artinya menyimpan, Lotup artinya meletup atau bergelembung akibat panas/mendidih, sehingga Ai Sipatn Lotup berarti tempat penyimpanan air panas/kolam air panas (bahasa Bokidoh oleh Dayak Jangkang). Sumber air panas ini memiliki temperatur antara $55,6-57^{\circ} \mathrm{C}$ dan suhu udara sekitar $28^{\circ} \mathrm{C}$. Salah satu kajian biologis yang dapat dilakukan pada sumber air panas yaitu mengenai bakteri termofilik. Berdasarkan hasil isolasi yang dilakukan Manalu (2019) pada sumber air panas Ai' Sipatn Lotup telah ditemukan 11 anggota dari bakteri Actinomycetes. Isolat tersebut diduga memiliki potensi antifungi.

Salah satu jamur penyebab mikosis paling umum ialah jamur anggota genus Malassezia, khususnya pada spesies Malassezia furfur yakni penyebab penyakit panu (Gupta et al., 2004). Penyakit panu merupakan penyakit kulit dengan nama lain Pitiarisis Versikolor (PV). Kasus penyakit PV di indonesia belum dapat diketahuai dengan pasti, namun diperkirakan 40-50\% populasi dinegara tropis terkena penyakit ini. 
Kurangnya informasi megenai potensi Actinomycetes dari sumber air panas Ai' Sipatn Lotup, Kalimantan Barat dalam upaya mengendalikan fungi penyebab Pitiarisis Versikolor (PV), maka dilakukan penelitian ini untuk melihat potensi bakteri tersebut melalui uji daya hambat secara in vitro terhadap anggota genus Malasezia sp. (M1).

\section{BAHAN DAN METODE \\ Waktu dan Tempat Penelitian}

Penelitian ini dilaksanakan dari bulan April hingga Juli 2018. Peremajaan bakteri dan jamur dilakukan di Laboratorium Mikrobiologi, Fakultas Matematika dan Ilmu Pengetahuan Alam, Universitas Tanjungpura, Pontianak. Pengujian bakteri dan jamur dilakukan di Laboratorium Mikrobiologi Kesehatan, Mikrobiologi, PuslitBiologi Lembaga Ilmu Pengetahuan Indonesia (LIPI), Cibinong, Bogor, Jawa Barat.

\section{Bahan}

Bahan yang digunakan dalam penelitian ini terdiri atas agar, akuades, alkohol 70\%, etanol 96\%, iodium, ketokenazole 2\%, isolat bakteri Actinomycetes hasil isolasi dari Ai' Sipant Lotup oleh Manalu (2019), isolat jamur Malassezia sp. (M1), Kristal violet, media Malt Extract Agar (MEA), media Malt Extract Broth (MEB), media NA.

\section{Prosedur Kerja \\ Sterilisasi Alat}

Alat-alat yang tahan panas dibersihkan terlebih dahulu dengan sabun di air mengalir, kemudian dibungkus dengan kertas dan plastik. Kemudian disterilisasi menggunakan autoklaf dengan tekanan $2 \mathrm{~atm}$ dan suhu $121^{\circ} \mathrm{C}$ selama 15 menit (Gunawan et al., 2004).

\section{Pembuatan Media}

Pembuatan media MEA (Malt Ekstrak Agar), MEB (Malt Ekstrak Broth), NA (Nutrient Agar) dan NB (Nutrient Broth) dengan cara menimbang masingmasing media MEA, MEB, NA dan NB dimasukkan ke dalam beaker glass dan ditambahkan akuades sebanyak 1L. Komponen bahan dihomogenkan dan dipanaskan hingga mendidih. Setelah mendidih dimasukan kedalam wadah gelas (erlenmeyer) kemudian disterilisasi kedalam autoklaf selama 15 menit dengan suhu $121^{\circ} \mathrm{C}$ tekanan $1 \mathrm{~atm}$ (Atlas, 2010).

Peremajaan Isolat Jamur dan Isolat Actinomycetes Isolat jamur Malassezia sp. (M1) diinokulasi dengan jarum ose ke dalam, media agar MEA kemudian diinkubasi pada suhu $25-30^{\circ} \mathrm{C}$ selama 35 hari hingga diperoleh pertumbuhan yang normal (Brooks et al., 2005). Isolat Actinomycetes diinokulasikan menggunakan jarum ose ke dalam media NA kemudian diinkubasi pada suhu $50{ }^{\circ} \mathrm{C}$ selama 3-5 hari hingga diperoleh pertumbuhan normal.

\section{Pembuatan Suspensi Jamur Uji}

Koloni jamur disuspensikan ke dalam $\mathrm{NaCI}$ fisiologis sebanyak $5 \mathrm{ml}$. Suspensi mikroba uji diukur dengan alat spektrofotometer UV-Vis dengan panjang gelombang $530 \mathrm{~nm}$ dengan (Depkes, 1995).

\section{Pembuatan Supernatan Isolat Bakteri Actinomycetes.}

Satu ose isolat bakteri anggota Actinomycetes pada cawan petri diinokulasikan ke dalam media NB 10 $\mathrm{ml}$, kemudian diinkubasi selama 96 jam pada suhu $50^{\circ} \mathrm{C}$. Suspesi bakteri tersebut di filter menggunakan shiring filter ukuran $0,22 \mu \mathrm{m}$ pada jam ke-96. Supernatan hasil filter dimasukan kedalam tabung reaksi.

\section{Uji Daya Hambat isolat Actinomycetes Terhadap Malassezia sp. (M1)}

Uji daya hambat bakteri terhadap Malassezia sp. (M1) dilakukan dengan metode difusi kertas cakram. Suspensi Malassezia sp. (M1) OD (Optical Density) 0,1 diinokulasikan ke dalam media MEA dengan metode apus (swap methode). Kertas cakram diameter $6 \mathrm{~mm}$ direndam ke dalam supernatan isolat bakteri Actinomycetes selama 1520 menit, kemudian diletakan di atas media MEA yang telah di inokulasi jamur Malassezia sp. (M1) lalu diinkubasi selama 48 jam untuk melihat zona hambat yang dihasilkan. Zona hambat diukur menggunakan jangka sorong.

\section{HASIL DAN PEMBAHASAN \\ Hasil}

Isolat Actinomycetes yang digunakan untuk menghambat fungi uji Malassezia sp. (M1) pada penelitian ini, ialah: isolat $\mathrm{S} 31$, isolat $\mathrm{S} 311 \mathrm{~A}$, isolat $\mathrm{S} 311$, isolat $\mathrm{H} 21$, isolat $\mathrm{H} 2232$, isolat $\mathrm{S} 21$, isolat $\mathrm{H} 22 * 1$, isolat $\mathrm{H} 12$, isolat $\mathrm{S} 211$, isolat $\mathrm{H} 11$, isolat H24. Kontrol positif yang digunakan yaitu ketokenazole 2\%. Berdasarkan hasil uji aktivitas antifungi terdapat 2 isolat yang mampu menghambat pertumbuhan jamur uji yakni isolat S311A (Microbispora sp.) dan H2232 (Streptomyces sp.). Penghambatan tersebut ditandai 
dengan terbentuknya zona bening disekitar kertas cakram (Gambar 1). Berdasarkan klasifikasi respon zona hambat, isolat S311A tergolong dalam penghambatan kuat dengan rata-rata ukuran zona penghambatan $12,83 \mathrm{~mm}$. Isolat $\mathrm{H} 2232$ tergolong
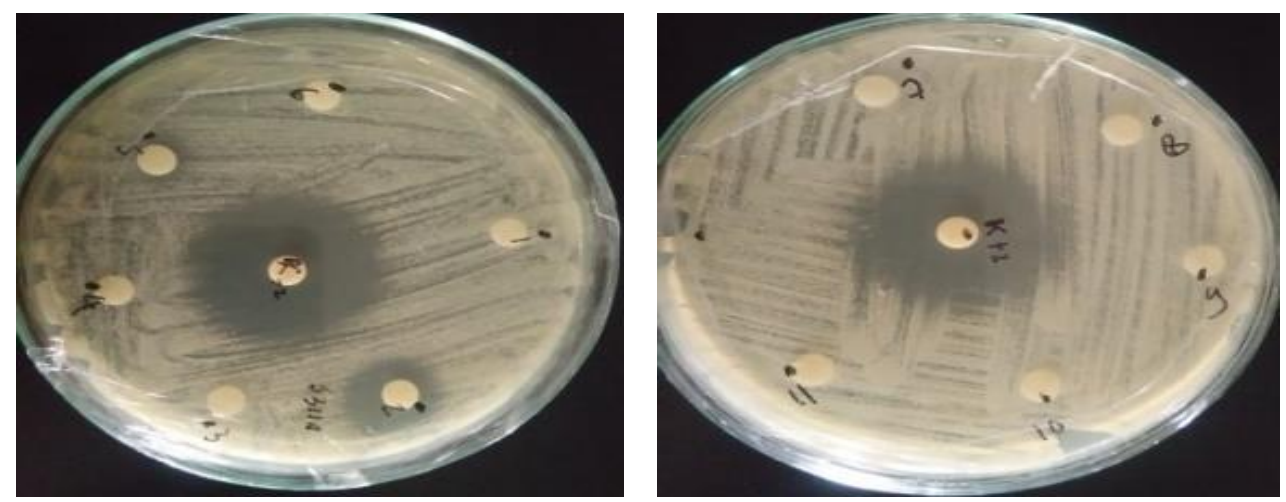

Gambar 1. Zona Hambat Supernatan Isolat Bakteri Actinomycetes Terhadap Jamur angota genus Malassezia Sp. (M1).

Ket : 1. Isolat S31, 2. Isolat S311A, 3. Isolat S311, 4. Isolat H21, 5. Isolat H2232, 6. Isolat S21, 7. Isolat H22*1, 8. Isolat $\mathrm{H} 12,9$. Isolat $\mathrm{S} 211,10$. Isolat $\mathrm{H} 11,11$. Isolat $\mathrm{H} 24,12 . \mathrm{K}+2$ (ketokenezole 2\%).

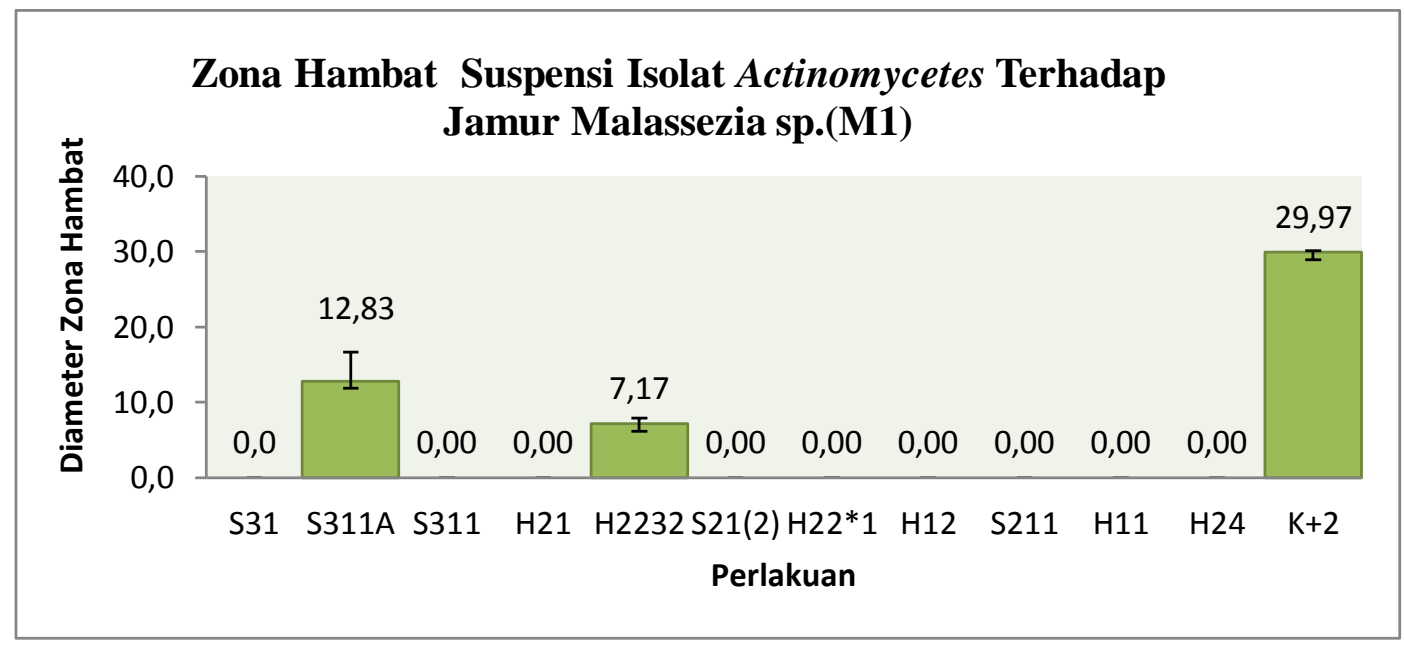

Gambar 2. Grafik diameter zona hambat suspensi isolat Actinomycetes terhadap jamur Malassezia sp. (M1).

\section{Pembahasan}

Hasil pengukuran zona hambat menggunakan jangka sorong menunjukan bahwa 2 dari 11 isolat Actinomycetes memiliki penghambatan terhadap jamur uji Malassezia sp (M1) (Gambar 1). Davis dan stout (1971) membagi kedalam 4 kategori kekuatan daya hambat, yakni sangat kuat (zona hambat $>20 \mathrm{~mm}$ ), kuat (zona hambat 10-20 mm), sedang (zona hambat 5-10 mm) dan lemah (zona hambat $<5 \mathrm{~mm})$. Berdasarkan kriteria tersebut dapat dilihat bahwa isolat S311A memiliki aktivitas penghambatan kuat dengan menghasilkan zona hambat sebesar $12,83 \mathrm{~mm}$. Isolat $\mathrm{H} 2232$ memiliki aktivitas penghambatan sedang terhadap jamur Malassezia sp. (M1) ke dalam aktivitas penghambatan sedang dengan nilai rata-rata zona yang dibentuk sebesar 7, $17 \mathrm{~mm}$. (Gambar 2). 
Kelompok pertama dengan mekanisme terjadi gangguan pada membran sel oleh senyawa turunan polien yang menyebabkan terjadinya kebocoran pada membran sel jamur sehingga menyebabkan kematian pada sel jamur contoh senyawanya antara lain, Nistatin, Amfoterisin B dan Kandisidin. Kelompok kedua senyawa antifungi yang mampu menghambat ergesterol dalam sel jamur adalah senyawa turunan imidazol sehingga menyebabkan ketidakseimbangan metabolik sel jamur contohnya, Ketokonazol, Klortimazol, Mikonazol, Bifonazol. Mekanisme golongan ketiga mengganggu sintesis asam nukleat dan protein. Mekanisme ini disebabkan oleh senyawa turunan pirimidin yang membentuk senyawa metabolik antagonis kemudian bergabung dengan asam ribonukleat dan menghambat sintesis asam nukleat dan protein jamur.

Pada penelitian ini telah diketahui bahwa isolat S311A dan H2232 memiliki metabolit sekunder yang mampu menghasilkan antifungi. Mekanisme pembentukan metabolit sekunder yang dihasilkan oleh isolat S311A dan H2232 diduga dibentuk pada saat terjadi cekaman nutrisi atau miskin nutrisi. Bibb (2005), Van dan Mc. Dowall (2011) menyatakan bahwa senyawa metabolit sekunder mikroba filamentous dibentuk pada saat mengalami cekaman atau kondisi miskin nutrisi. Menurut Mendez et al (1985) dan Migueles et al (1999) kondisi ini terjadi pada fase miselium substrat berdefersiasi membentuk struktur hifa sporogenik (hifa reproduktif) kemudian membentuk miselium aerial, lalu mengalami degredasi autolitik yang terprogram oleh PCD (Programmed Cell Death) atau biasa disebut dengan peristiwa Apoptosis. Peristiwa inilah yang menyebabkan terjadinya sistem pertahanan nutrisi dengan memproduksi senyawa metabolit sekunder yang dikeluarkan di sekitar sel, sehingga dapat menghambat pertumbuhan atau membunuh mikroba pesaing. Mikroba yang di uji atau mikroba pesaing dalam penelitian ini ialah jamur anggota spesies Malassezia sp (M1).

Kontrol positif yang digunakan pada penelitian ini ialah ketokenazole 2\%. Menurut Brunton et al. (2010) Ketokenazol merupakan obat antifungi turunan dari azol yang baik digunakan untuk menghambat pertumbuhan fungi. Mekanisme kerja obat ini menurut Katzung et al. (2011) yakni dengan menghambat biosintesis ergosterol pada membran sitoplasma sel fungi dan menyebabkan akumulasi metilsterol. Metilsterol ini dapat mengganggu rantai asil fosfolipid, merusak fungsi sistem enzim pada membran sel, sehingga menghambat pertumbuhan jamur.

Beberapa spesies dari genus Microbispora dan genus Steptomyces diketahui mampu menghasilkan metabolit sekunder yang bersifat antifungi. Menurut savi et al., (2014) Microbispora sp. LGMB259 menghasilkan metabolit sekunder yang mampu melawan fungi Sacaromyces cerevisae ATCC209508, Phyllosticta citricarpa LGMB06 dan Colletricum gloeosporioides FDCD83. Patil et al., pada tahun 2013 juga melaporkan Microbispora sp. V2 mampu menghambat fungi patogen yakni Scleretium rolfsii dengan tingkat penghambat 91,43\%. Selain genus Microbispora, anggota genus Streptomyces juga dikenal sebagai agen penghasil antifungi. Barka et al. (2016) merangkum sekitar 21 jenis spesies yang memproduksi senyawa antifungi antara lain, Streptomyces anulatus yang memproduksi Actinomycins, Streptomyces griseochromogenes memproduksi Blasticidin, Streptomyces griseus memproduksi Candicidin, Streptomyces venezuelae memproduksi Chloramphenicol dan lain lain. Beberapa ilmuan seperti Kumar et al. (2014) dan Balachandran et al. (2015) juga telah menemukan kemampuan genus Streptomyces dalam menghambat fungi genus Malassezia, khususnya pada spesies Malassezia pachydermatis.

\section{UCAPAN TERIMA KASIH}

Penulis menghaturkan terimakasih yang sebesarbesarnya kepada Kepala laboratorium Mikrobiologi LIPI Dr. Atit kanti M.sc, dan pembimbing di laboratorium mikrobiologi Bidang kesehatan Dra. Titin yulinery.

\section{DAFTAR PUSTAKA}

Akbar, Rifqi, Aulia, Ryandini, Dini \& Kusharyati Dyah Fitri, 2017, 'Potensi Aktinomisetes Asal Tanah Perakaran Mangrove Segara Anakan Cilacap Sebagai Penghasil Anti-jamur Terhadap Candida albicans', Journal of Tropical Biodiversity and Biotechnology, Vol. 2, hal 39-44.

Atlas, Ronald, M, 2010, Hand Book of Mikrobiologycal Media Fourth Edition, ASM press, Washington D.C. 
Ayari, A, Morakchi, H, \& Djamila, K.G, 2016, Isolation of Antifungal Activity of Novel Marine Actinomycete, Streptomyces sp. AA13 Isolated from Sediments of Lake Ougeria (Algeria) Against Candida albicans', African Journal of Microbiology Reseacrh, Vol. 10, No.6, hal 156-171.

Barka, E, A, Parul, V, Lisa S, Nathalie G, V, Cedric, J, Hans P, K, Christophe, C, Yder, O \& Gilles P V W, 2016, 'Taxonomy, Physiology, and Natural Products of Actinobacteria', Microbiology and Molecular Biology Reviews, Vol. 80, No.1.

Berdy, J, 2005, 'Bioactive microbial metabolites', Journal Antibiotic, vol. 58, hal. 1-26.

Bibb, MJ, 2005, 'Regulation of secondary metabolism in Streptomycetes', Curr Opin Microbiol Vol. 8, hal 208-215.

Brooks, G,F, Carroll, K, C, Butel, J, S, \& Morse, S, A, 2007, Jawetz Melnick and Adelberg's Medical Microbiology $24^{\text {th }} e d$, The McGrawHill Companies, Inc, United States of America.

Deepa S K, Kanimozhi \& A, Panneerselvam, 2013, '16S rDNA Phylogenetic Analysis of Actinomycetes Isolated from Marine Environment Associated with Antimicrobial Activities', journal for drugs and medicines, Vol.5, No 2.

Depkes RI,1995, Farmakope Indonesia (Edisi ke 4), Depertemen Kesehatan RI, Jakarta.

Dewi, A, K, 2014, 'Aktivitas Antifungai Isolat Actinomycetes dari Sampel Pasir Gunung Merapi dengan Lama Fermentasi yang Berbeda Terhadap Candida albicans', Skripsi, Fakultas Keguruan dan Ilmu Pendidikan UMS, Surakarta.

Endo, A, \& Misato, T, 1969, 'Polyoxin D, a competitive inhibitor of UDP-Nacetylglucosamine: chitin N-acetyl glucosaminyltransferase in Neuro-spora crassa', Biochem Biophys Res Commun 37 : 718-722, $\quad$ http://dx.doi.org/10.1016/0006291X(69)90870-5.

Gunawan, A, W, Dharmaputra, O, S, \& Rahayu, G, 2004, Cendawan dalam Praktik Laboratorium, IPB Press, Bogor.

Gupta, A, K, R, Batra, R, Bluhm, T, Boekhout, T, L, \& Dawson, Jr, 2004,'Skin diseases associated with Malassezia species', Journal of the American Academy of Dermatology, vol. 51, no. 5, hal 785-798.
Isono, K, Nagatsu, J, Kawashima, Y \& Suzuki, S, 1965, 'Studies on polyox ins, antifungal antibiotics, Part I Isolation and characterization of polyoxins A and B', Agric Biol Chem, Tokyo, vol 29, hal, 848-854.

Manalu, Jerliman, Rahmawati, \& Novik, Nurhidayat, 2019, 'Aktivitas Antifungi Isolat Actinomycetes dari Sumber Air Panas Ai Sipatn Lotup Sanggau Terhadap Isolat Hortaea werneckii (T1)', Protobiont, Vol. 8 (1), hal. $69-77$.

Katzung, B, G, Susan, B, M, \& Anthony JT, 2011, Basic and clinical pharmacology Ed $12^{\text {th }}$, McGraw-Hill, California.

Kumar, P, S, Duraiandiyan, V, \& S, Ignacimuthu, 2014, 'Isolation Screaning And Partial Purification Antimicrobial Antibiotik From Soil Streptomyces'. Kaohsiun Journal Of Medical Sciences, Vol 10, hal 1-12.

Mendez, C, Braña, AF, Manzanal, MB \& Hardisson, C, 1985, 'Role of substrate mycelium in colony development inStreptomyces', Can Jornal Microbiol $31: 446-450$, http://dx.doi.org/10.1139/m85-083.

Miguelez, E, M, Hardisson, C, \& Manzanal, MB, 1999, 'Hyphal death during colony development in Streptomyces antibioticus: morphological evi-dence for the existence of a process of cell deletion in a multicellular prokaryote', Journal Cell Bio, 1145:515-525, http://dx.doi.org/10.1083/jcb.145.3.

Ong, C,w, Chan, Y,S, Khoo, K,S, Ong, H,C \& Sit, N,W, 2018, 'Antifungal and Cytotoxic Activities Of Extracts Obtained From Underutilised Edible Tropical Fruits', Asian Pacific Journal of Tropical Biomedicine, Vol.1, No.6, hal. 313-319.

Patel, M, G, Horan, A, C, Marquez, J, A, \& Waitz, J A, 1990, 'Antifungal triacetylene dioxolone from Microbispora sp. SCC1438 ATCC 53620', U.S, Patent 4, 956, 383.

Savi, D, C, Khaled, A, S, Nathalia, V, Larissa V, Ponomareva, Yvelise, M, P, Jon S, T, Chirlei, $\mathrm{G}$, \& Jürgen, R, 2015, 'Microbispora sp. LGMB259 Endophytic Actinomycete Isolated from Vochysia divergens (Pantanal, Brazil) Producing b-Carbolines and Indoles with Biological Activity', Curr Microbiol 70:345354. 
Protobiont (2019) Vol. 8 (2) : 104 - 109

Van, Wezel, G, P, \& McDowall, K,J, 2011, 'The regulation of the secondary metabolism of Streptomyces', new links and experimental advances, Nat Prod Rep 28: 1311 - 1333, http://dx.doi.org/10.1039/c1np00003a.

Waluyo, Lud, 2008, Petunjuk Praktek Mikrobiologi, UMM Press, Malang. 